\title{
Serological Surveillance of Influenza D Virus in Ruminants and Swine in West and East Africa, 2017-2020
}

\author{
Idrissa Nonmon Sanogo ${ }^{1,2} \mathbb{D}^{\mathbb{D}}$, Casimir Kouakou ${ }^{3}$, Komla Batawui ${ }^{4}$, Fidélia Djegui ${ }^{5}$, Denis K. Byarugaba ${ }^{6,7}$ (D), \\ Rachidatou Adjin 5 , Komlan Adjabli ${ }^{4}$, Fred Wabwire-Mangen 6,7, Bernard Erima ${ }^{7}$, Gladys Atim ${ }^{7}$, \\ Qouilazoni A. Ukuli ${ }^{7}$, Titus Tugume ${ }^{7}$, Koffi Dogno ${ }^{4}$, Wolali Go-Maro ${ }^{4}$, Emmanuel Couacy-Hymann ${ }^{3}{ }^{\mathbb{D}}$, \\ Ghazi Kayali $^{8,9}$, Pamela McKenzie ${ }^{10}$, Richard J. Webby ${ }^{10}$ and Mariette F. Ducatez ${ }^{1, *}$
}

\section{check for} updates

Citation: Sanogo, I.N.; Kouakou, C.; Batawui, K.; Djegui, F.; Byarugaba, D.K.; Adjin, R.; Adjabli, K.;

Wabwire-Mangen, F.; Erima, B.; Atim, G.; et al. Serological Surveillance of Influenza D Virus in Ruminants and Swine in West and East Africa, 2017-2020. Viruses 2021, 13, 1749. https://doi.org/10.3390/v13091749

Academic Editors: Chao-Nan Lin and Peck Toung Ooi

Received: 27 July 2021

Accepted: 30 August 2021

Published: 2 September 2021

Publisher's Note: MDPI stays neutral with regard to jurisdictional claims in published maps and institutional affiliations.

Copyright: (c) 2021 by the authors. Licensee MDPI, Basel, Switzerland. This article is an open access article distributed under the terms and conditions of the Creative Commons Attribution (CC BY) license (https:// creativecommons.org/licenses/by/ $4.0 /)$.
1 Interactions Hôtes-Agents Pathogènes (IHAP), UMR 1225, Université de Toulouse, ENVT, INRAE, 31076 Toulouse, France; idrissa.sanogo@envt.fr

2 Faculté d'Agronomie et de Médecine Animale (FAMA), Université de Ségou, Ségou BP 24, Mali

3 Laboratoire National d'Appui au Développement Agricole (LANADA), Bingerville BP 206, Côte d'Ivoire; casymyr2006@yahoo.fr (C.K.); chymann@gmail.com (E.C.-H.)

4 Laboratoire Central Vétérinaire de Lomé, Lomé BP 4041, Togo; dbatawui@yahoo.fr (K.B.); fo_mathias@yahoo.fr (K.A.); koffipolo001@yahoo.fr (K.D.); emilygomaro@yahoo.fr (W.G.-M.)

5 Laboratoire de Diagnostic Vétérinaire et de Sérosurveillance (LADISERO), Parakou BP 23, Benin; djegui_fidelia@yahoo.fr(F.D.); adjinrachidath@yahoo.fr (R.A.)

6 College of Veterinary Medicine Animal Resources and Biosecurity, Makerere University, Kampala P.O. Box 7062, Uganda; denis.byarugaba@mak.ac.ug (D.K.B.); fwabwire@musph.ac.ug (F.W.-M.)

7 Makerere University Walter Reed Project, Kampala P.O. Box 16524, Uganda; berima@muwrp.org (B.E.); gatim@muwrp.org (G.A.); qukuli@muwrp.org (Q.A.U.); ttugume@muwrp.org (T.T.)

8 Human Link, Dubai Multi Commodity Center (DMCC), Dubai 48800, United Arab Emirates; ghazi@human-link.org

9 Health Sciences Center, University of Texas, Houston, TX 77030, USA

10 Department of Infectious Diseases, St. Jude Children's Research Hospital, Memphis, TN 38105, USA; Pamela.McKenzie@stjude.org (P.M.); richard.webby@stjude.org (R.J.W.)

* Correspondence: mariette.ducatez@envt.fr; Tel.: +33-5611-932-49

Abstract: Influenza D virus (IDV) was first isolated in 2011 in Oklahoma, USA from pigs presenting with influenza-like symptoms. IDV is known to mainly circulate in ruminants, especially cattle. In Africa, there is limited information on the epidemiology of IDV, although the virus has likely circulated in the region since 2012. In the present study, we investigated the seropositivity of IDV among domestic ruminants and swine in West and East Africa from 2017 to 2020. Serum samples were analyzed using the hemagglutination inhibition (HI) assay. Our study demonstrated that IDV is still circulating in Africa, with variations in seropositivity among countries and species. The highest seropositivity was detected in cattle (3.9 to 20.9\%). Our data highlights a need for extensive surveillance of IDV in Africa in order to better understand the epidemiology of the virus in the region.

Keywords: influenza D virus; Africa; cattle; small ruminants; swine; epidemiology; serology

\section{Introduction}

Influenza viruses are members of the Orthomyxoviridae family and are divided into four types (A, B, C, D). Animals are mainly infected by influenza type A and D viruses [1,2]. Influenza D Virus (IDV) was first isolated in 2011 in Oklahoma, USA from pigs presenting with flu-like symptoms [3]. After its first isolation, IDV has been detected in other countries in America [4], Europe [5-8] and Asia [9,10]. Serological studies showed the circulation of IDV in many countries in Africa [11-13], suggesting a worldwide geographic distribution of the virus.

Evidence for IDV infection has been found in a large number of animal species, such as cattle, sheep, goats [14,15], pigs and wild boars [16], dromedary camels [12] and horses [17]. Cattle are the main host of IDV, contributing to the spread of the virus to other 
animal species $[5,18,19]$. IDV is considered to play a role in the bovine respiratory disease complex [4], which is responsible for huge economic losses for the livestock sector globally. In addition to animals, IDV-specific antibodies have been found in humans, with very high seroprevalence among people exposed to cattle, thus suggesting the zoonotic potential of the virus $[20,21]$.

In Africa, there is limited information on the epidemiology of IDV, although evidence suggests that the virus may have been circulating in the region since at least 2012 [11]. Studies in Kenya and Ethiopia [11,12] showed substantially higher seroprevalence in camelids (99\%), suggesting the importance of the species in the epidemiology of IDV in Africa. In Morocco (North Africa), 35\% of cattle sera collected were positive for anti-IDV antibodies [11]. In West Africa, lower seropositivity rates for IDV were reported in cattle $(1.9-10.4 \%)$ and small ruminants $(1.4-2.2 \%)$ [11]. To date, no antibodies were detected in pigs in Africa, and attempts to isolate the virus have been unsuccessful [11,13].

The capacity of IDV to infect humans and numerous other animal species, and the ability of influenza viruses to regularly mutate, make this virus a continuing threat to animal and public health. Therefore, it is necessary to carry out further research on this virus. In this study, we aimed to investigate the seropositivity of IDV among domestic ruminants and swine in West and East Africa from 2017 to 2020 and to compare these results with previously available data.

\section{Materials and Methods}

\subsection{Serum Samples Collection}

From 2017 to 2020, we conducted a prospective serosurveillance for IDV in four countries in Sub-Saharan West and East Africa (Figure 1). A total of 3381 sera were collected from apparently healthy adult domestic ruminants and swine either from farms, cattle markets or slaughterhouses. Immediately after collection, the samples were stored in a cool box at $+4{ }^{\circ} \mathrm{C}$ and transferred to the laboratory within $24 \mathrm{~h}$. Animal health status and sex, as well as the date and place of sampling, were recorded. Sera samples collected in Togo during a previous study on IDV were also included in this study [13].

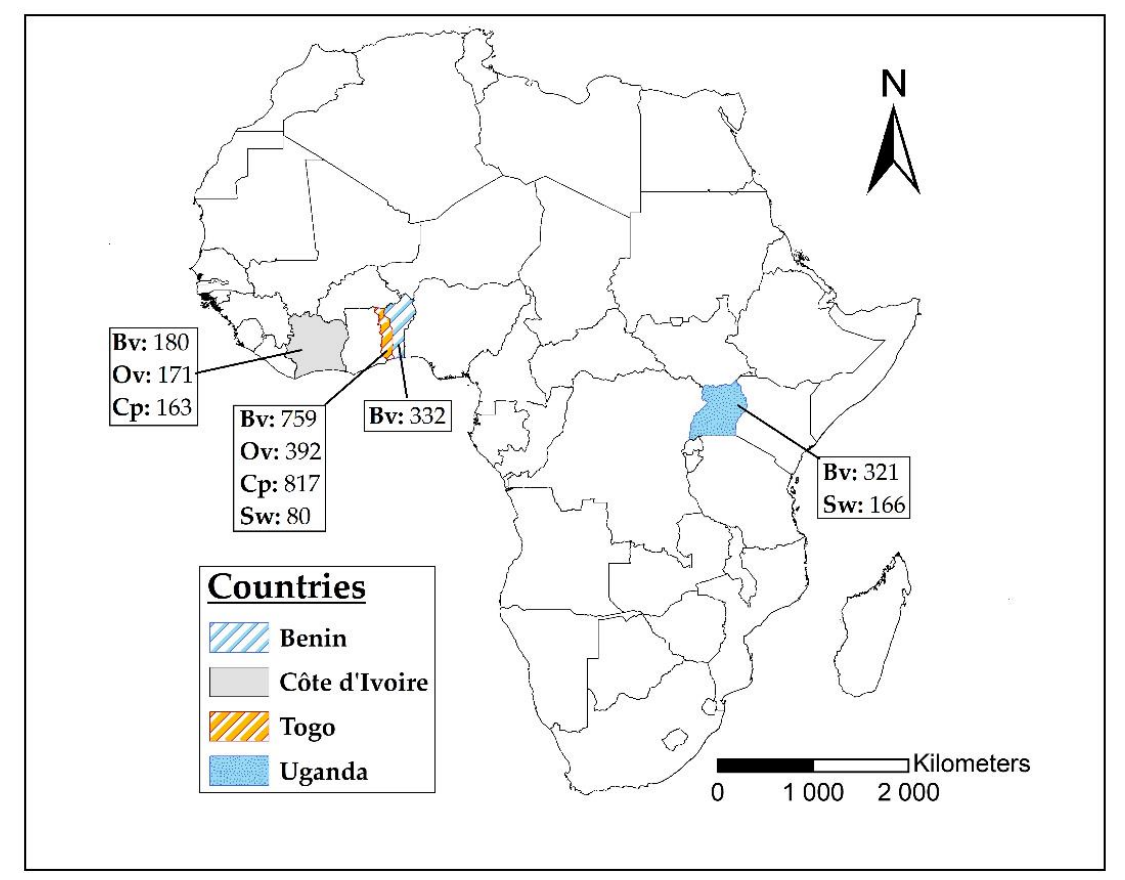

Figure 1. Map of countries where sera were collected. The number of samples collected from each species is indicated. Bv: cattle; Ov: sheep; Cp: goat; Sw: swine. In Uganda, all sera were collected in slaughterhouses. The map was designed using ArcMap 10.4 (ESRI, Redlands, CA, USA). 


\subsection{Serological Analysis}

For the detection of IDV antibodies in serum, hemagglutination inhibition (HI) tests were performed using D/bovine/France/5920/2014 as the antigen and 1\% chicken red blood cells for hemadsorption according to the procedures described by Salem et al. [11]. The HI titer was expressed as the reciprocal of the highest serum dilution showing complete inhibition of hemagglutination. A serum sample was determined as seropositive when the $\mathrm{HI}$ titer was $\geq 1: 10[11,22]$.

\subsection{Data Analysis}

Data were recorded into a standard Excel spreadsheet in Microsoft Excel 2016 (Microsoft corporation, Seattle, WA, USA). The anti-IDV seropositivity in each country and animal species was calculated as the number of sera with a titer greater than or equal to 1:10 out of the total number of sera tested. Statistical analyses were carried out with RStudio Desktop 1.4 software (RStudio Inc., Boston, MA, USA). The Chi-square test of independence was performed to test the relationship between the prevalence of anti-IDV antibodies and different explanatory variables (species, sex and place of sampling) at a level of significance of $5 \%(p \leq 0.05)$. We then examined the effects of species, countries and sex, individually, on the odds of seropositivity to IDV by using the epi.2by2 function of the epiR package in RStudio Desktop 1.4 (RStudio, Inc., Boston, MA, USA).

\section{Results}

\subsection{Seropositivity of IDV in Cattle, Sheep, Goats and Swine}

The results of $\mathrm{HI}$ analyses revealed that anti-IDV antibodies were present in a percentage of serum samples from all four animal species (Table 1). Out of the 3381 samples collected, $232(6.9 \%)$ were positive for IDV antibodies. The highest seropositivity rate for IDV $(20.9 \%)$ was observed in cattle in Uganda. Seropositive swine were also detected only in Uganda. Sheep and goats had much lower seropositivity ( 2 to $4.4 \%$ ) than did cattle. HI titers observed in positive samples ranged from 10 to 640 , with the highest titers seen in cattle and swine sera. When selecting 20 instead of 10 as a threshold titer for positive sera, very similar results were obtained.

Table 1. Seropositivity rates of influenza D virus (IDV) in cattle, sheep, goat and swine in four countries of West and East Africa.

\begin{tabular}{ccccccc}
\hline Country & $\begin{array}{c}\text { Sampling } \\
\text { Period }\end{array}$ & $\begin{array}{c}\text { Animal } \\
\text { Species }\end{array}$ & $\begin{array}{c}\text { Number } \\
\text { of Tested } \\
\text { Samples }\end{array}$ & $\begin{array}{c}\text { Number } \\
\text { of Positive } \\
\text { Samples }\end{array}$ & $\begin{array}{c}\text { Positivity } \\
\text { Rate (\%) }\end{array}$ & $\begin{array}{c}\text { HI Titer } \\
\text { Range }\end{array}$ \\
\hline Benin & $2017-2019$ & Cattle & 332 & 13 & 3.9 & $20-80$ \\
\hline \multirow{2}{*}{ Côte } & \multirow{2}{*}{2019} & Cattle & 180 & 13 & 7.2 & $10-80$ \\
d'Ivoire & Sheep & 171 & 7 & 4.1 & $10-40$ \\
& & Goat & 163 & 6 & 3.7 & $10-40$ \\
\hline \multirow{2}{*}{ Togo } & \multirow{2}{*}{$2017-2020$} & Cattle & 759 & 48 & 6.3 & $10-320$ \\
& & Sheep & 392 & 8 & 2 & $10-80$ \\
& & Goat & 817 & 36 & 4.4 & $20-160$ \\
\multirow{2}{*}{ Uganda } & \multirow{2}{*}{$2017-2019$} & Swine & 80 & 0 & - & - \\
\hline & Cattle & 321 & 67 & 20.9 & $10-160$ \\
& & Swine & 166 & 34 & 20.5 & $10-640$ \\
\hline
\end{tabular}

\subsection{Factors Associated with IDV Seropositivity}

We next determined what factors were associated with IDV seropositivity. The variables that had a statistically significant association with IDV seropositivity are presented in Table 2. Cattle were more likely to be seropositive than goats or sheep (OR $=0.48$ for goats and $\mathrm{OR}=0.30$ for sheeps $p<0.001$ ); however, swine had 1.5 times higher odds ( $\mathrm{OR}=$ $1.56, p=0.03$ ) of being seropositive to IDV in comparison to cattle. Additionally, cattle 
in Uganda had a higher risk of being infected by IDV than in other countries (OR 5.33, $p<0.001)$.

Table 2. Factors associated with anti-IDV seropositivity rates among cattle, sheep, goat and swine in four countries of West and East Africa.

\begin{tabular}{cccccc}
\hline Variable & Categories (N) & $\mathbf{n ~ ( \% )}$ & OR & $\mathbf{9 5 \%}(\mathbf{C I})$ & $p$ \\
\hline \multirow{4}{*}{ Species } & Cattle (1592) & $141(8.9)$ & RF & & \\
& Goat (980) & $42(4.3)$ & 0.48 & $0.34-0.69$ & $<0.001$ \\
& Sheep (563) & $15(2.7)$ & 0.30 & $0.18-0.52$ & $<0.001$ \\
& Swine (246) & $34(13.6)$ & 1.56 & $1.05-2.32$ & 0.03 \\
\hline \multirow{3}{*}{ Countries * } & Benin (332) & $13(3.9)$ & RF & & \\
& Côte d'Ivoire (180) & $13(7.2)$ & - & - & 0.1 \\
& Togo (759) & $48(6.3)$ & - & - & 0.1 \\
& Uganda (321) & $67(20.9)$ & 5.33 & $2.89-9.84$ & $<0.001$ \\
\hline \multirow{2}{*}{ Sex } & Male (1456) & $90(6.2)$ & RF & & \\
& Female (1925) & $142(7.4)$ & - & - & 0.2 \\
\hline N:
\end{tabular}

N: number of samples tested; $n$ : number of positive samples; \%: proportion of positive samples; OR: odds ratios CI: confidence interval; RF: reference factor; $p$ values $\leq 0.05$ are considered statistically significant; * For these countries, only cattle sera were considered.

There was no significant difference between seropositivity in cattle in Benin, Côte d'Ivoire and Togo. Moreover, there was no statistically significant difference in seropositivity by sex.

\section{Discussion}

In this study, we determined the prevalence of anti-IDV antibodies among domestic ruminants and swine in West and East Africa. Our results confirm that IDV is still circulating in the region, as previously shown by other studies in Africa [11,13]. However, in Benin and Côte d'Ivoire, our data showed higher IDV seropositivity in cattle than seen in prior studies assessing sera collected between 1991-2015 (1.9\% and 0\%, respectively). Conversely, IDV seropositivity in cattle in Togo in our study was lower than that seen in sera collected from 1991-2015 (10.4\%). We did find a higher IDV seropositivity rate in cattle in Togo (6.3\%) compared with data previously reported between 2017-2019 (4.5\%), suggesting that the virus continues to circulate widely.

IDV seropositivity in cattle differed significantly between countries in West and East Africa. These differences between countries might be related to the variability in husbandry practices, as previously suggested [14].We found that Uganda had the highest IDV seropositivity rate in cattle. This finding may be the result of the importance of the cattle population in Uganda (16.3 million heads in 2019) compared to the other three countries in West Africa (Benin: 2.5 million; Côte d'Ivoire: 1.7 million; Togo: 0.5 million heads) [23]. The higher seropositivity in Uganda might also be partly explained by the high number of camels in East Africa (60\% of the world population in the horn of Africa), as camels have been postulated to contribute to the persistence of IDV in Africa [12,24]. Nevertheless, further serological and virological studies are required to better understand the role played by camels in the epidemiology of IDV.

Seropositivity rates of IDV in domestic ruminants and swine and HI titers in Africa are much lower than those observed in other continents $[8,14,19]$. Antigenically different IDV strains were isolated in many regions of the world [5]. In this study, the virus we used for the HI test was D/bovine/France/5920/2014, isolated in France, and classified as a D/swine/Oklahoma-like virus. It cannot be ruled out that antigenically different IDV strains may be circulating in Africa, lowering the sensitivity of our assay.

Our data indicated a higher IDV seropositivity rate in cattle compared to the other animal species. These results are in line with data reported in European countries [8]. Indeed, cattle are considered as the main host for IDV, contributing to its spread. Furthermore, high 
levels of IDV antibodies were reported in newborn calves [19]; our study focused only on adult animals as they are the ones found in livestock markets and slaughterhouses.

Our study provides the first serological evidence of IDV in swine in Africa. Previous studies have reported IDV in swine in France [16] and Italy [6]. However, IDV is circulating at lower levels in swine compared with cattle, but at higher levels than in sheep [15]. Our study found higher odds for swine to be seropositive to IDV when compared with cattle. However, the number of swine sera was limited and only collected in Togo and Uganda, underpowering our study to some degree.

The results presented in this study, while commendable, should be treated cautiously because they are based on convenience samples. In addition, we did not carry out any confirmatory serological tests, such as ELISA or microneutralization assays. Thus, largescale and well-designed studies based on random samples are needed to expand on our results.

In summary, our findings confirm that IDV is circulating among domestic animals in West and East Africa, albeit at lower rates than observed in other regions. We identified evidence of variation in IDV seropositivity among different countries and species. Nevertheless, as our study was based on non-random samples, further serological and virological studies are needed to investigate the epidemiology of IDV in Africa and to examine its potential threat to public health.

Author Contributions: Conceptualization, I.N.S. and M.F.D.; methodology, I.N.S., C.K., R.A., K.A., and M.F.D.; formal analysis, I.N.S. and M.F.D.; investigation, I.N.S., C.K., K.B., F.D., D.K.B., R.A., K.A., B.E., G.A., Q.A.U., T.T., K.D., W.G.-M., E.C.-H. and M.F.D.; resources, K.B., F.W.-M., G.K., P.M., R.J.W. and M.F.D.; data curation, I.N.S.; writing-original draft preparation, I.N.S. and M.F.D.; writingreview and editing, I.N.S., D.K.B., E.C.-H., G.K., P.M., R.J.W. and M.F.D.; project administration, F.D., D.K.B., W.G.-M., E.C.-H., G.K., P.M., M.F.D.; funding acquisition, R.J.W. and M.F.D. All authors have read and agreed to the published version of the manuscript.

Funding: This study was founded by the National Institute of Allergy and Infectious Diseases, National Institutes of Health (CEIRS contract no. HHSN272201400006C). I.N.S. is supported by a PhD scholarship of the French Embassy in Mali.

Institutional Review Board Statement: This study was approved by the St. Jude Children's Research Hospital Institutional Animal Care and Use Committee (Amended IACUC Approval \# 546-10049107/17; expires 4/5/23).

Informed Consent Statement: Not applicable.

Data Availability Statement: The data presented in this study are available upon request to the corresponding author.

Acknowledgments: The authors would like to thank Maxime Fusade-Boyer, Maria Gaudino, Adrien Lion, and Gilles Meyer (IHAP, France) for fruitful discussions.

Conflicts of Interest: The authors declare no conflict of interest.

\section{References}

1. Ducatez, M.F.; Webster, R.G.; Webby, R.J. Animal influenza epidemiology. Vaccine 2008, 26, 67-69. [CrossRef] [PubMed]

2. Asha, K.; Kumar, B. Emerging influenza D virus threat: What we know so far! J. Clin. Med. 2019, 8, 192. [CrossRef] [PubMed]

3. Hause, B.M.; Ducatez, M.; Collin, E.A.; Ran, Z.; Liu, R.; Sheng, Z.; Armien, A.; Kaplan, B.; Chakravarty, S.; Hoppe, A.D.; et al. Isolation of a novel swine influenza virus from oklahoma in 2011 which is distantly related to human influenza C viruses. PLoS Pathog. 2013, 9. [CrossRef]

4. Mitra, N.; Cernicchiaro, N.; Torres, S.; Li, F.; Hause, B.M. Metagenomic characterization of the virome associated with bovine respiratory disease in feedlot cattle identified novel viruses and suggests an etiologic role for influenza D virus. J. Gen. Virol. 2016, 97, 1771-1784. [CrossRef]

5. Ducatez, M.F.; Pelletier, C.; Meyer, G. Influenza D virus in cattle, France, 2011-2014. Emerg. Infect. Dis. 2015, $21,368-371$. [CrossRef]

6. Chiapponi, C.; Faccini, S.; De Mattia, A.; Baioni, L.; Barbieri, I.; Rosignoli, C.; Nigrelli, A.; Foni, E. Detection of influenza D virus among swine and cattle, Italy. Emerg. Infect. Dis. 2016, 22, 352-354. [CrossRef] [PubMed] 
7. Flynn, O.; Gallagher, C.; Mooney, J.; Irvine, C.; Ducatez, M.; Hause, B.; McGrath, G.; Ryan, E. Influenza D virus in cattle, Ireland. Emerg. Infect. Dis. 2018, 24, 389-391. [CrossRef]

8. Gaudino, M.; Moreno, A.; Snoeck, C.J.; Zohari, S.; Saegerman, C.; O’Donovan, T.; Ryan, E.; Zanni, I.; Foni, E.; Sausy, A.; et al. Emerging influenza D virus infection in European livestock as determined in serology studies: Are we underestimating its spread over the continent? Transbound. Emerg. Dis. 2020, 68, 1-11. [CrossRef]

9. Jiang, W.-M.; Wang, S.-C.; Peng, C.; Yu, J.-M.; Zhuang, Q.-Y.; Hou, G.-Y.; Liu, S.; Li, J.-P.; Chen, J.-M. Identification of a potential novel type of influenza virus in Bovine in China. Virus Genes 2014, 49, 493-496. [CrossRef]

10. Murakami, S.; Endoh, M.; Kobayashi, T.; Takenaka-Uema, A.; Chambers, J.K.; Uchida, K.; Nishihara, M.; Hause, B.; Horimoto, T. Influenza d virus infection in herd of cattle, Japan. Emerg. Infect. Dis. 2016, 22, 1517-1519. [CrossRef]

11. Salem, E.; Cook, E.A.J.; Lbacha, H.A.; Oliva, J.; Awoume, F.; Aplogan, G.L.; Couacy Hymann, E.; Muloi, D.; Deem, S.L.; Alali, S.; et al. Serologic evidence for influenza C and D virus among ruminants and camelids, Africa, 1991-2015. Emerg. Infect. Dis. 2017, 23, 1556-1559. [CrossRef] [PubMed]

12. Murakami, S.; Odagiri, T.; Melaku, S.K.; Bazartseren, B.; Ishida, H.; Takenaka-Uema, A.; Muraki, Y.; Sentsui, H.; Horimoto, T. Influenza D virus infection in dromedary camels, Ethiopia. Emerg. Infect. Dis. 2019, 25, 1224-1225. [CrossRef]

13. Fusade-Boyer, M.; Pato, P.S.; Komlan, M.; Dogno, K.; Batawui, K.; Go-Maro, E.; McKenzie, P.; Guinat, C.; Secula, A.; Paul, M.; et al. Risk mapping of influenza D virus occurrence in ruminants and swine in togo using a spatial multicriteria decision analysis approach. Viruses 2020, 12, 128. [CrossRef]

14. Oliva, J.; Eichenbaum, A.; Belin, J.; Gaudino, M.; Guillotin, J.; Alzieu, J.P.; Nicollet, P.; Brugidou, R.; Gueneau, E.; Michel, E.; et al. Serological evidence of influenza D virus circulation among cattle and small ruminants in France. Viruses 2019, 11, 516. [CrossRef]

15. O'Donovan, T.; Donohoe, L.; Ducatez, M.F.; Meyer, G.; Ryan, E. Seroprevalence of influenza D virus in selected sample groups of Irish cattle, sheep and pigs. Ir. Vet. J. 2019, 72, 11-13. [CrossRef]

16. Gorin, S.; Fablet, C.; Quéguiner, S.; Barbier, N.; Paboeuf, F.; Hervé, S.; Rose, N.; Simon, G. Assessment of influenza D virus in domestic pigs and wild boars in France: Apparent limited spread within swine populations despite serological evidence of breeding sow exposure. Viruses 2019, 12, 25. [CrossRef]

17. Nedland, H.; Wollman, J.; Sreenivasan, C.; Quast, M.; Singrey, A.; Fawcett, L.; Christopher-Hennings, J.; Nelson, E.; Kaushik, R.S.; Wang, D.; et al. Serological evidence for the co-circulation of two lineages of influenza D viruses in equine populations of the Midwest United States. Zoonoses Public Health 2018, 65, e148-e154. [CrossRef] [PubMed]

18. Hause, B.M.; Collin, E.A.; Liu, R.; Huang, B.; Sheng, Z.; Lu, W.; Wang, D.; Nelson, E.A.; Li, F. Characterization of a novel influenza virus in cattle and swine: Proposal for a new genus in the Orthomyxoviridae family. MBio 2014, 5. [CrossRef] [PubMed]

19. Luo, J.; Ferguson, L.; Smith, D.R.; Woolums, A.R.; Epperson, W.B.; Wan, X.F. Serological evidence for high prevalence of influenza D viruses in cattle, Nebraska, United States, 2003-2004. Virology 2017, 501, 88-91. [CrossRef] [PubMed]

20. Trombetta, C.M.; Marchi, S.; Manini, I.; Kistner, O.; Li, F.; Piu, P.; Manenti, A.; Biuso, F.; Sreenivasan, C.; Druce, J.; et al. Influenza D virus: Serological evidence in the Italian population from 2005 to 2017. Viruses 2019, 12, 30. [CrossRef]

21. White, S.K.; Ma, W.; McDaniel, C.J.; Gray, G.C.; Lednicky, J.A. Serologic evidence of exposure to influenza D virus among persons with occupational contact with cattle. J. Clin. Virol. 2016, 81, 31-33. [CrossRef] [PubMed]

22. Saegerman, C.; Salem, E.; Ait Lbacha, H.; Alali, S.; Zouagui, Z.; Meyer, G.; Ducatez, M.F. Formal estimation of the seropositivity cut-off of the hemagglutination inhibition assay in field diagnosis of influenza D virus in cattle and estimation of the associated true prevalence in Morocco. Transbound. Emerg. Dis. 2021, 68, 1392-1399. [CrossRef] [PubMed]

23. FAO FAOSTAT. Available online: http:/ / www.fao.org/faostat/en/\#home (accessed on 5 July 2021).

24. Faye, B. The camel today: Assets and potentials. Anthropozoologica 2014, 49, 167-176. [CrossRef] 